Re-Usable Vice-Style SEM

Sample Holders for Pin-Mount Stages

Ben Simkin, Michigan State University simkin@egr.msu.edu

Over a number of years, I have found it desirable to firmly hold a sample in the SEM without the contamination problems (or sample creep) associated with carbon tape. My approach to this has been to make a small vice suitable for gripping the sample which will still fit into a standard pin-mount style sample stage. I have made a number of specimen holders over the last few years, at rock-bottom prices. My recipe for a pin-mount style mini-vice is:

1) Grind or cut a small block of brass to the vice size desired.

2) Drill one hole in the large face of the block the size of the pin (typically around $3 \mathrm{~mm}$ ).

3) Drill two parallel holes (the size for tap holes) through the long axis of the block.

4) Cut off one end of the block perpendicular to the two tap holes.

5) Tap the holes in the larger section of the block.

6) Drill out the tap holes in the smaller section of the block to make clearance holes.

7) Cut off a length of brass rod for the pin mount, and solder it in place in the hole in the larger block.

8) Screw two bolts (brass recommended) into the large block through the clearance holes in the smaller block. This is the mini-vice.

9) De-burr, clean, and polish as desired.

For microscope stages that take a different style mount, the brass rod can be replaced with the appropriate adaptor. I have made these as small as $5 \mathrm{~mm}$ on a side to as large as about 40 $\mathrm{mm}$. The only limit is the size of the SEM's chamber and the load limit of the stage. With proper tools several of these can be made in an hour; with hand tools and what is available from the local hobby store, maybe 1.5 to 2 hours each.

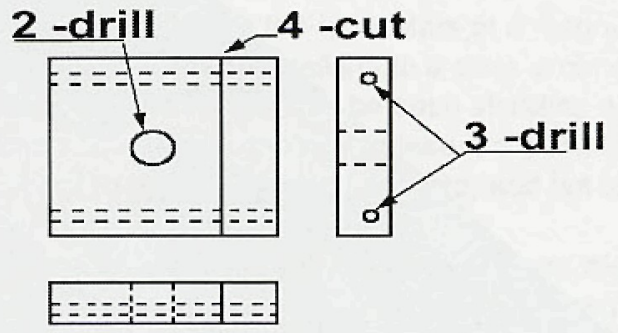

INITIAL BLOCK

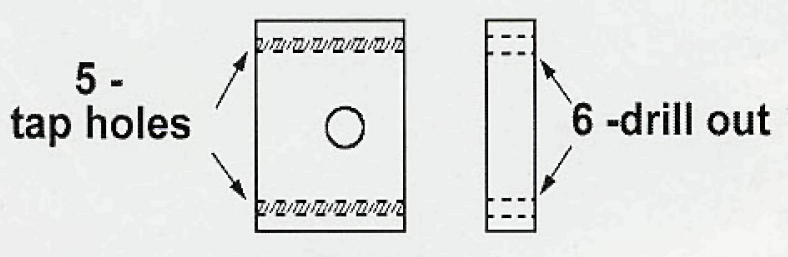

AFTER CUTTING

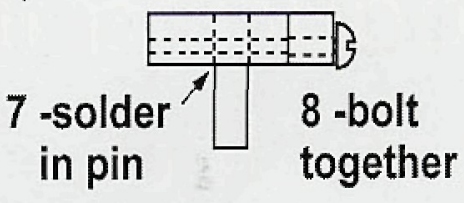

FINAL ASSEMBLY

\title{
INDEX OF ARTICLES
}

Re-Usable Vice-Style SEM Sample Holders .3

For Pin-Mount Stages

Ben Simkin, Michigan State University

Manufacturing and Processing Techniques Affecting.

Morphology of Pyrotechnic Oxidizer Particles

Richard C. Dujay, Mesa State College

Ken Kosanke, PyroLabs, Inc.

Digital Subtraction Of Lipofuscin"s Fluorescence. .14

Anda Cornea, Oregon Health Sciences University

Marijuana Identification: A Test for Calcium in

Cystolithic Hairs

Baruch Glattstein \& Azriel Gorski, Israel National Poli ce

On Measuring Section Thickness 17

Ron Doole, University of Oxford

Watching Neurons Hand Off Molecules.

Stephen Carmichael, Mayo Clinic
Monitoring Electron Microscope Performance 20 Steve Chapman, Protrain, UK

Cleaning A Microscope's Optical Surfaces 26 Jeffrey M. Larson, Nikon Instruments

HMDS Preparation of Cell Monolayers Grown on. 28

Thermanox Coverslilps for SEM

Dorothy Roak Sorenson, Univ. of Michigan Medical School

Cold Vs. Schottky Guns

Tony Garrett-Reed, MIT

Another Tip Collecting Serial Ultrathin Sections.....

Tim Schneider, Thomas Jefferson University

Another Lens Cleaning Tip

Robert Fitton, Luther College

The "Whistle" Test..

Mary Mager, University of British Columbia 


\section{CORRECTION: M\&M 2001 Housing Information:}

The correct web address to make hotel reservations at M\&M 2001 is: www.pkghlrss.com/events/mm2001.html

To fax your reservations, simply download the housing form from the above site and fax it to (562)590-9366. Phone number for questions only (no reservations) is (562)436-3645, ext. 111

BTW we are advised that the Hyatt is full!

\section{Attention M\&M 2001 Exhibitors!}

Once again, MSA's Education Committee is organizing mini-seminars or tutorial demonstrations known as "Exhibitor Demonstrations". These sessions are conducted by Exhibitors right in their own booth(s) on Tuesday, August 7, 2001, from 5:00 - 6:00 pm. Exhibitor Demonstrations are the perfect way to make attendees more knowledgeable about your products/services, at no charge to you or the attendee. Admission is limited and controlled by tickets issued at the Education Committee Booth on the Exhibit Floor.

Participating exhibitors will be listed on a sign at the entrance to the Exhibit Hall on Monday and Tuesday. There will also be individual signs provided for the booths identifying them as participating Exhibitors.

If you are interested in offering an Exhibitor Demonstration, please contact Tina Carvalho (University of Hawaii) of MSA's Education Committee: eMail (preferred): tina@pbrc. hawaii.edu, Tel.: (808)956-6251

\section{MICROSCOPY SOCIETY OF AMERICA AWARDS}

Distinguished Scientist Awards

(Physical \& Biological Sciences)

\section{Burton Medal}

OIA-MSA Outstanding Young Investigator Award

Outstanding Technologist Awards

(Physical \& Biological Sciences)

\section{Mort Maser Distinguished Service Award}

All MSA members are encouraged to nominate candidates for the above Awards to recognize our eminent scientific and society leaders.

Details are available from the MSA Business Office:

BusinessOffice@MSA.Microscopy.Com

Deadline for receipt of completed nominations is $15 \mathrm{De}$ cember 2001.

\section{EQUIPMENT FOR SALE:}

Nestor Zaluzec, in addition to establishing and maintaining the Microscopy Listserver, has established two web sites to assist in the sale of equipment-one for used equipment and one for new equipment.

Used Equipment: called the "Surplus Equipment Forum" is where any individual can post an electronic advertisement to dispose of surplus equipment. The URL is: http://www.msa. microscopy.com/SurplusEquipment/SurplusListing.html

While there is no charge for this service, donations from sales to MSA to help support the site would be greatly appreciated. However, surplus equipment offered only for the cost of shipping/handling may still be listed on the Microscopy Listserver.

New Equipment: called the "Vendor News Forum" is where manufacturers and suppliers can post information relating to their products and services. The URL is:

http://www.msa.microscopy.com/News/NewsListing.html

\section{MICROSCOPE MAINTENANCE COMPANIES}

Rosemary White (CSIRO in Australia) recently searched in the U.S. for microscope maintenance companies and came up with the following list-which was published on the Microscopy Listserver:

www.southernmicro.com (Georgia)

www.dscoptical.com/services.htm (near Boston)

www.caleywhitmore.com (near Boston)

www.opticalexpertise.com (New York)

www.mwrn.com/product/microscope/repair.htm (several)

www.sciscope.com/field-service.htm (lowa, most states)

www.svms.com/services/index.html (Silicon Valley)

www.meyerinst.com/html/mts.htm (Texas)

www.microresource.com/services2.htm (Illinois)

www.allometrics.com/microscope_serv.htm (Lousiana/Texas)

www.labworksinc.com (San Francisco)

www.biotherm_inc.com (5 Southern States)

www.mikroni.com/fp/fp/services.htm (San Diego)

www.uams.edu/oas/OES/oesilab.htm (Arkansas)

www.uni.edu/pur/maintenance/equipment.html (U. of N. lowa)

www.dominionmicroscope.com/services.htm (Richmond VA)

For companies involved in microscope maintenance and not listed, advise Microscopy Today (microtoday@mindspring.com) and we will list in a future summary.

\section{FRONT COVER IMAGE}

The image is of a two-headed seahorse embryo, Hippocampus zosterae. It was found in the collections of fixed embryos at the Gulf Coast Research Laboratory \& Museum in Ocean Springs, Mississipt. It was scoped with a JEOL 35CF at Presbyterian College, mag.: $73 \mathrm{X}$. Except for some minor repair with Abode Photoshop for a tear in the tissue along the back (probably during drying), it is untouched.

Image compliments of Jim Wetzel, Presbyterian College 


\section{The Funniest (True?) Story Ever!}

The following story was provided by an unknown source. As a result we can not suggest that it is really true. However, I do suggest that there is a "ring of truth" in it! ....Ed.

This has got to be one of the funniest l've heard of in a long time. I think this guy should have been promoted, not fired. This is a true story from the Word Perfect Helpline which was transcribed from recording monitoring the customer care department. Needless to say the HelpDesk employee was fired; however, he/she is currently suing the WordPerfect organization for "Termination without Cause." The actual dialogue of a former WordPerfect Customer Support employee follows:

Q: "Ridge Hall computer assistance; may I help you?"

A: "Yes, well, I'm having trouble with WordPerfect."

Q: "What sort of trouble?"

A: "Well I was just typing along, and all of a sudden the words went away."

Q: "Went away?"

A: "They disappeared."

Q: "Hmm. So what does your screen look like now?"

A: "Nothing."

Q: "Nothing?"

A: "It's blank; it won't accept anything when I type."

Q: "Are you still in WordPerfect or did you get out?"

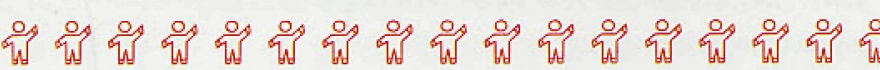

\section{SEM Slow Scan Image Acquisition}

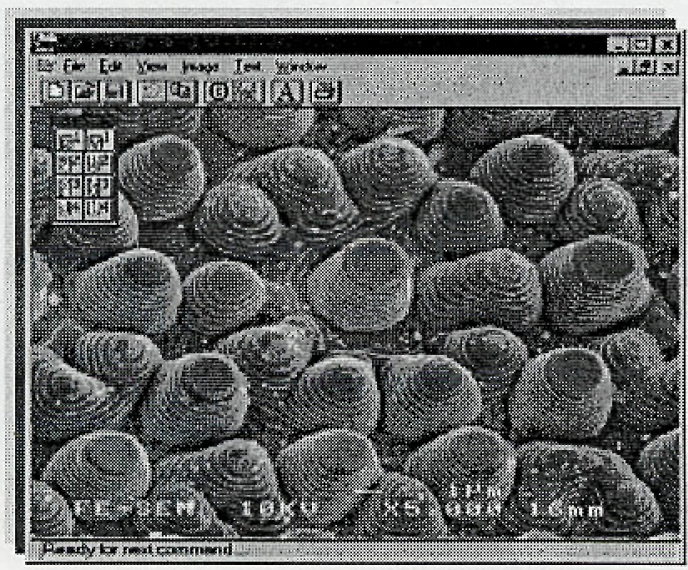

\section{Advanced DataBase Systems. Inc.}

\section{SEMages - Features}

- Easy to install and operate

- Passive beam accuisitian

- 95. '98. NT4.0, 2000 \& ME compliant

- Compatible with analog \& digital SEMs

- Affardable. single card solution

- Image Graphics and theasuring tools

303.761 .5635 or http://www,adsdb,com 2750 S. Shashone St. Englewrod CO 80110
A: "How do I tell?"

Q: "Can you see the C-prompt on the screen?"

A: "What's a sea-prompt?"

$\mathrm{Q}$ : "Never mind. Can you move your cursor around the

screen?"

A: "There isn't any cursor: I told you, it won't accept anything I type"

Q: "Does your monitor have a power indicator?"

A: "What's a monitor?"

Q: "It's the thing with the screen on it that looks like a TV. Does it have a little light that tells you when it's on?"

A: "I don't know?"

$\mathrm{Q}$ : "Well, then look on the back of the monitor and find where the power cord goes into it. Can you see that?"

A: "Yes, I think so".

Q: "Great. Follow the cord to the plug, and tell me if it's plugged into the wall."

A: "Yes it is"

Q: "When you were behind the monitor, did you notice that there were two cables plugged into the back of it, not just one?"

A: "No."

Q: "Well, there are. I need you to look back there again and find the other cable."

A: "Okay, here it is"

Q: "Follow it for me, and tell me if it's plugged securely into the back of your computer"

A: "I can't reach it."

Q: "Uh huh. Well, can you see if it is?"

A: "No."

Q: "Even if you put your knee on something and leaned way over?"

A: "Oh, it's not because I don't have the right angle - it's be cause it's dark."

Q: "Dark?"

A: "Yes the office light is off, and the only light I have is coming in from the window."

Q: "Well, turn on the office light then."

A: "I can't."

Q: "No? Why not?"

A: "Because there's a power failure."

Q: "A power failure? AHA, Okay, we've got it licked now. Do you still have the boxes and manuals and packing stuff your computer came in?"

If A: "Well, yes, I keep them in the closet."

Q: "Good. Go get them, and unplug your system and pack it up just like it was when you got it. Then take it back to the store you bought it from."

A: "Really? Is it that bad?"

Q: "Yes, I'm afraid it is."

A: "Well, all right then, I suppose. What do I tell them?"

Q: "Tell them you're too f__ g stupid to own a computer." 


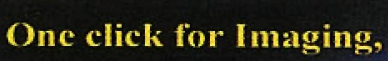

YEAR 2001 APPLIED OPTICAL MICROSCOPY CALENDAR Smithsonian Ctr for Materials Research \& Educ. (Suitland, MD)

$\checkmark$ July 16/20: Polarized Light Microscopy-Fundamentals \& Applications

$\checkmark$ Aug. 14/16: Interpretation of Archaeological metals

$\checkmark$ Aug. 20/24: Wood Anatomy and Identification

$\checkmark$ Sept 17/21: Microscopy of Protective and Decorative Coatings For further information: Ms. Francine Lewis: (301)238-3700 X102

YEAR 2001 MCCRONE RESEARCH INSTITUTE SCHEDULE:

$\checkmark$ May 30/June 1: Fluorescence Microscopy

$\checkmark$ Sept. 5/7: Microtomy

$\checkmark$ Sept. 10/14: Advanced FTIR Microscopy

$\checkmark$ Sept. 24/26: Caking of Crystals

$\checkmark$ Nov. 5/9: Particle Isolation, Manipulation and mounting for Additional Analysis

$\checkmark$ Nov. 12/16: Scanning Electron Microscopy

For further information, contact Ms. Nancy Daerr: (312)842-7100, Fax: (312)842-1078, eMail: ndaerr@mcri.org

$\checkmark$ May 21/23 '01: Immunogold Workshop, (Penn State Univ.) University Park, PA. Hong Yi: (404)727-8692

$\checkmark$ May 21/25 '01: FE-SEM and Image Analysis Courses Montreal, Canada. Dr. Pierre Hovington: (450)652-8125, eMail: hovington. pierre@ireq.ca

$\checkmark$ May 22/24 01: Fundamentals of Asbestos Analysis by TEM (MVA, Inc.) Norcross, GA, Jim Millette: (770)662-8509

$\checkmark$ May 22/29 '01: Microinjection Techniques In Cell Biology (Marine Biological Laboratory) Woods Hole, MA. (508)289-7401

$\checkmark$ May 29-June 28 '01: Biological TEM Summer Session (Nassau Community College) Garden City, L.I., www.sunynassau.edu/webpages/ biology/becks.htm

$\checkmark$ June 6/8 '01: Workshop on Quantitative Image Analysis NC State Univ.), Taastrup, Denmark, http://www.ncsu.edu/cpe

$\checkmark$ June 6/8 '01: Microscopical Society of Canada Annual Meeting Fredericton, New Brunswick, Canada, http://www.unb.ca/msc2001

$\checkmark$ June 8/10 '01: FRET and FLIM: Advanced Fluorescence Techniques for Biological Imaging. (U. of T. Health Science Ctr) San Antonio, TX, http://usa.hamamatsu.com/fretflim

\section{LEHIGH MICROSCOPY SCHOOL}

$\checkmark$ June 11/15 '01: SEM and X-ray Microanalysis

$\checkmark$ June 10, '01: Introduction to SEM and EDS

$\checkmark$ June 18/22 '01: Advanced Scanning Electron Microscopy Quantitative X-ray Microanalysis

$\checkmark$ June 18/21 '01: Analytical Transmission Electron Microscopy

$\checkmark$. June 19/21 01: TEM Specimen Preparation

$\checkmark$ June 19/22 01: Atomic Force Microscopy

For further information, contact Ms. Sharon Coe at: tel.: (610)758-

5133, fax: (610)758-4244, eMail: sharon.coe@lehigh.edu

$\checkmark$ June 17/22 101: 3rd Annual Course in Quantitative Fluorescence Microscopy Arcadia Nat'l Park, ME, Simon C. Watkins: (412)648-3051

$\checkmark$ June 18/21 '01: 17th Annual Short Course on Molecular Microspectroscopy (Miami University) Oxford OH. (513)529-2874

$\checkmark$ June 18/28 01: 6th Annual International Short Course on 3D Microscopy of Living Cells and:

$\checkmark$ June 30/July 2 '01: 5th Workshop on 3D Image Processing.

Univ. of British Columbia, Vancouver, B.C., www.cs.ubc.ca/spider/ladic/ course/bulletin.html

$\checkmark$ July 2/6 '01: 16th International Conference on X-ray Optics and Microanalysis (ICXOM XVI), Vienna, Austria, www.icxom at

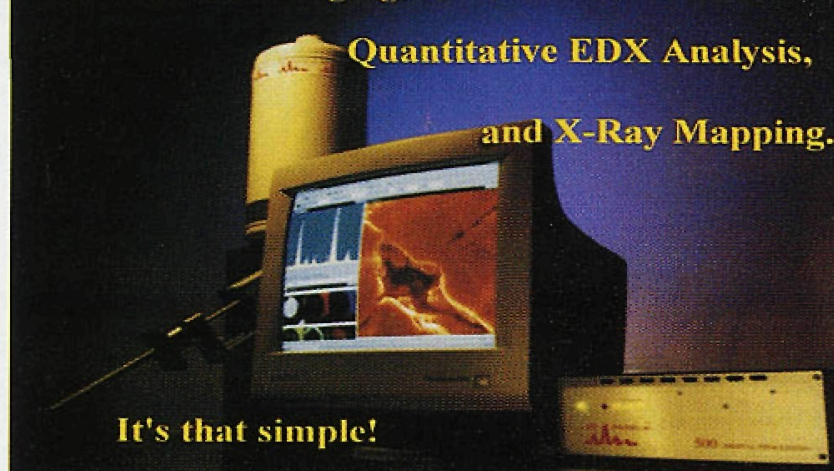

Digital Pulse Processing Electronics

High-Resolution Light-Element Si(Li) Detectors High-Resolution Digital Imaging

Accurate and Fast Quantitative Analysis Position-Indexed Spectroscopy

Automatic and Customized Particle/Feature Analysis? Free Software Updates

Excellent Technical Support

Best Price/Performance Ratio in the Industry

Did we miss something?

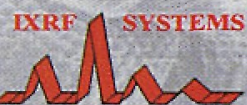

IXRF Systems, Inc.

15715 Brookford Drive

Houston, TX 77059

Tel: (281) 286-6485 Fax: (281) 286-2660

http://www.ixrfsystems.com

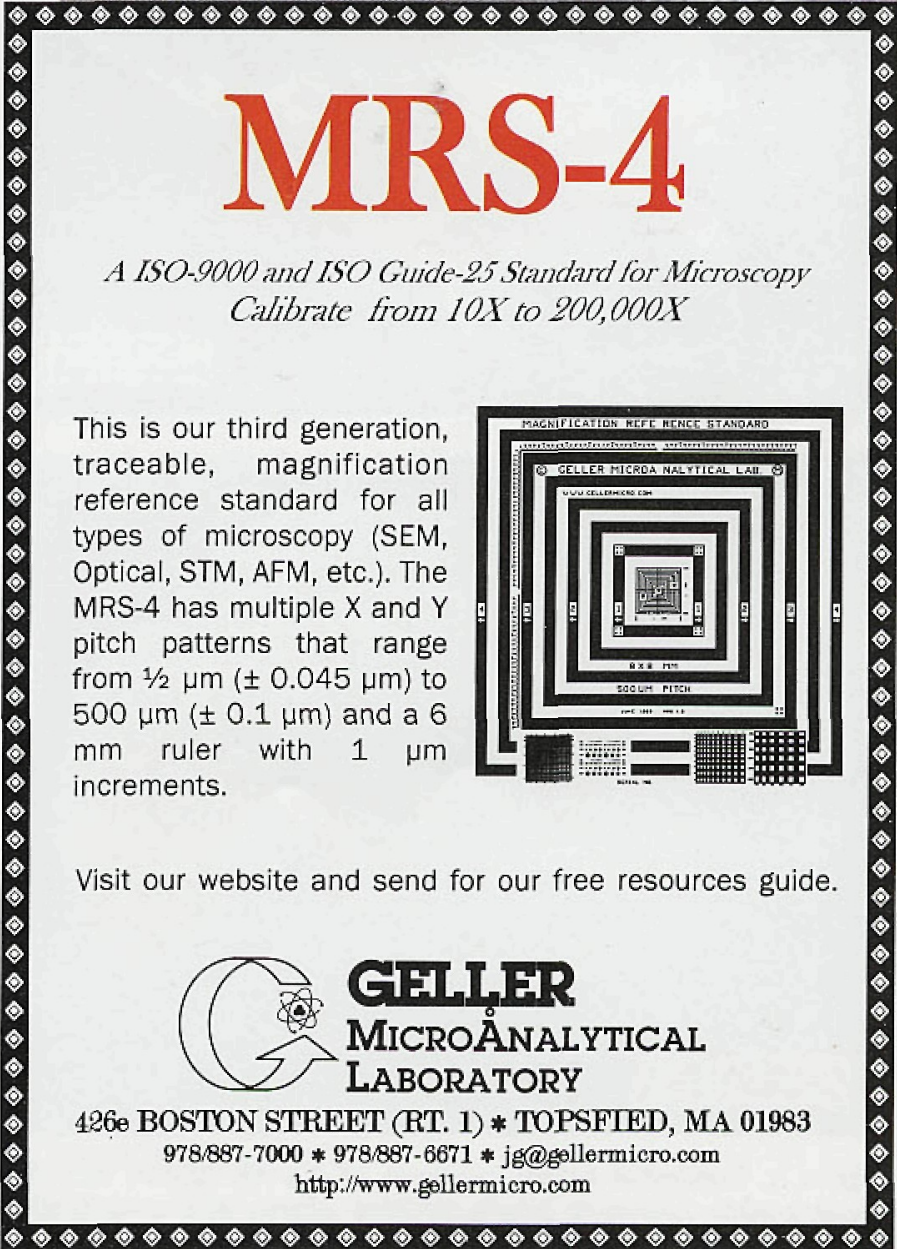

